\title{
A synopsis of Rhinacanthus (Acanthaceae) in Angola and Namibia
}

\author{
lain Darbyshire ${ }^{1}$ D, Leevi Nanyeni ${ }^{2}$, Frances M. Chase $^{2}$ \& Francisco M. P. Gonçalves ${ }^{3}$
}

Summary. The three species of the genus Rhinacanthus Nees occurring in Angola and Namibia are documented, including a full description of the new species $R$. angolensis I. Darbysh. and an expanded description of the scarce species R. kaokoensis K. Balkwill \& S. D. Will. A key to their identification is provided, together with notes on their conservation status and species affinities.

Key Words. conservation, Guineo-Congolian, IUCN Red List assessment, justicioid, Kaokoveld, new species, taxonomy.

\section{Introduction}

The genus Rhinacanthus Nees (in Wallich 1832: 76) comprises 25 - 30 species, found mainly in tropical Africa, Madagascar and the Indian Subcontinent. Within the Acanthaceae, it is placed in the Diclipterinae clade of the "justicioid" lineage (McDade et al. 2000). Rhinacanthus is morphologically similar to Justicia L. sensu lato. It is distinguished by having the combination of a long, narrowly cylindrical corolla tube usually exceeding the length of the bilabiate limb and by the two stamens having bithecous anthers in which the thecae are offset and \pm oblique but, unlike in most Justicia, the lower thecae of each anther lacks a basal appendage or, if present, the appendage is poorly developed and inconspicuous (Darbyshire \& Harris 2006). In addition, it has a long-stipitate and shortly beaked 4 -seeded capsule.

The most recent molecular data on the "justicioid" lineage (Kiel et al. 2017) show that core Rhinacanthus, including species of the $R$. nasutus (L.) Kurz complex (sensu Darbyshire \& Harris 2006), forms a clade within Diclipterinae. However, that study suggests that the delimitation of Rhinacanthus may need some refining, particularly with regard to the enigmatic Kenyan endemic $R$. ndorensis Schweinf. ex Engl. which appears to be both morphologically and phylogenetically distinct from core Rhinacanthus. The African forest species $R$. virens (Nees) Milne-Redh. is also resolved outside core Rhinacanthus, although it is morphologically close to the $R$. nasutus complex.

The taxonomy of Rhinacanthus has been studied across much of its African range in the recent past, through a series of taxonomic papers and regional floristic treatments (Balkwill 1995; Darbyshire \& Harris 2006; Ensermu Kelbessa 2006, 2009; Thulin 2006; Darbyshire et al. 2010; Darbyshire 2012; Darbyshire et al. 2015). These works have collectively added nine new or resurrected names in African Rhinacanthus as well as one new record for the continent. A new species from Sri Lanka, R. flavovirens Amaras. \& Wijes., has also recently been described following studies of the genus in the southern Indian Subcontinent (Amarasinghe \& Wijesundara 2011), but further work is still much needed on the Asian members of the genus. This is also true for Madagascar, where preliminary research has indicated that four out of seven endemic species on the island are undescribed (Madagascar Catalogue 2017).

The major taxonomic challenge in Rhinacanthus is the complex group of species around $R$. nasutus. In an earlier synopsis of the African members of this group, Darbyshire \& Harris (2006) noted that two collections had been seen from south-western Angola (Pritchard 356 and Welwitsch 5010, both BM) that could not be placed with certainty. It was noted that, whilst these collections appear close to $R$. zambesiacus I. Darbysh. (wrongly named as $R$. gracilis Klotzsch in that paper; see Darbyshire 2012), they are geographically isolated from that species' known distribution. A study of the Acanthaceae collections at the LUBA herbarium has revealed three further collections of the Angolan taxon. Detailed examination of the five available collections has confirmed this to be a further new species within the $R$. nasutus complex, and it is described as Rhinacanthus angolensis I.

\footnotetext{
Accepted for publication 21 March 2018. Published online 3 May 2018

1 Herbarium, Royal Botanic Gardens, Kew, Richmond, TW9 3AB, Surrey, UK. e-mail: i.darbyshire@kew.org

2 National Herbarium of Namibia, Ministry of Agriculture, Water and Rural Development, National Botanical Research Institute, Private Bag 13184, Windhoek, Namibia.

3 Herbarium of Lubango, ISCED Huíla, Sarmento Rodrigues Str., C. P. 230, Lubango, Angola.
} 
Darbysh. below. At the same time, R. kaokoensis K. Balkwill \& S. D. Will. from northwest Namibia has been studied in detail by the authors of this paper for the forthcoming treatment of Acanthaceae in the new Flora of Namibia series (Chase 2017). New information on this species has come to light including confirmation of its presence in Angola. We therefore considered it useful to produce a synoptic treatment of the genus in Angola and Namibia here.

This work forms a part of ongoing taxonomic research into the Acanthaceae of Angola and Namibia. Acanthaceae species often form an ecologically important component of the vegetation in this region of Africa, with many species being locally abundant or dominant over large areas in the ground layer of open shrubland, desert and woodland. The Acanthaceae are also of potential conservation importance in view of the high number of localised and endemic species. For example, the genus Petalidium Nees has its centre of diversity in the Kaokoveld region of northwest Namibia and southwest Angola, "achieving densities unrivaled by other members of the family almost anywhere else on the planet" here, despite this being a hyper-arid region (Tripp et al. 2017: 3). Other important genera in terms of species richness and abundance in this region include Monechma Hochst. (sometimes treated as a synonym of Justicia L.), Blepharis Juss. and Barleria L. Recent studies in Acanthopsis Harv. (Steyn \& van Wyk 2015, 2016, 2017), Barleria L. (Darbyshire et al. 2012 \& in prep.; Nyirenda 2012), Hypoestes R. Br. (Darbyshire 2015), and Ruellia L. and allies (Tripp \& Dexter 2012; Tripp \& Darbyshire 2017) have revealed a number of new species and taxonomic changes, and there are sure to be further new discoveries as other genera are studied in detail. Excluding checklists (for example Craven 1999; Welman 2003; Klaassen \& Kwembeya 2013), the most recent treatment of the Acanthaceae of Namibia is by Meyer (1968), whilst there is no modern account of the family in Angola except for the checklist by Makholela (2008).

\section{Materials \& Methods}

This study is based primarily on the examination of herbarium specimens held at BM, K, LUBA and WIND, supplemented by field observations of Rhinacanthus kaokoensis and $R$. virens. All specimens cited in the "Collections studied" sections have been seen by the author except where indicated ("n.v.").

The species conservation assessments are based on the Categories and Criteria of IUCN (2012). The Extent of Occurrence (EOO) was calculated using the Kew Geospatial Conservation Assessment Tool GeoCAT (geocat.kew.org; Bachman et al. 2011). Area of Occupancy (AOO) is not used as a range measure for Rhinacanthus kaokoensis or $R$. angolensis in view of the fact that the Angolan range of these species is under-botanised and so an accurate measure of AOO is not deemed possible based on the limited occurrence records.

\section{Key to Rhinacanthus in Angola and Namibia}

1. Corolla with upper lip ovate or triangular-ovate; anthers with a short appendage on lower theca; plants of wet lowland and riverine forest $\ldots \ldots \ldots \ldots \ldots \ldots \ldots \ldots \ldots \ldots \ldots \ldots \ldots \ldots \ldots \ldots \ldots \ldots \ldots$ virens

Corolla with upper lip lanceolate; anthers with lower theca acute at base, lacking a short appendage; plants of

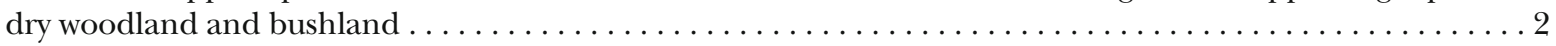

2. Inflorescence lacking capitate glandular hairs, flowers laxly arranged along the spiciform inflorescence axis and (if present) branches, flowers paired or often solitary at each inflorescence node; mid-cauline leaves with base typically rounded, truncate or widely cuneate . . . . . . . . R. kaokoensis

Inflorescence with numerous capitate glandular hairs, flowers held in fascicles at apices of inflorescence branches; mid-cauline leaves (if present at flowering) with base cuneate or attenuate $\ldots \ldots \ldots \ldots \ldots \ldots \ldots \ldots \ldots \ldots \ldots \ldots \ldots \ldots \ldots \ldots \ldots \ldots \ldots$ angolensis

\section{Taxonomic account}

1. Rhinancanthus kaokoensis K. Balkwill E S. D. Will. (in Balkwill 1995: 14). Type: Namibia, "am Kunene (Ruacana) bei Baken 1”, 13 April 1966, Giess 9289 (holotype WIND [WIND000032181]; isotypes K [K000378862], M [M0110651], PRE [PRE0483959-0], WIND [WIND000032182]).
R. nasutus sensu auctt., non (L.) Kurz: Benoist (1950: 26); Makholela (2008: 24).

R. xerophilus sensu Meyer (1968: 63), non A. Meeuse.

Suffruticose perennial herb, up to $90 \mathrm{~cm}$ high, stems densely hairy with short spreading to antrorse and retrorse pale hairs giving the stem a grey appearance, basal stems and rootstock woody. Leaves on petiole to $13 \mathrm{~mm}$ long, uppermost leaves subsessile; blade ovate 
to broadly so (basal leaves more elliptic), (1.5 -) 2.5 $8.7 \times(0.7-) 1.5-6.5 \mathrm{~cm}$, base rounded, truncate or widely cuneate or upper leaf pairs cordate, margin entire or somewhat undulate, apex acute, obtuse or sub-attenuate, sometimes with an apiculum; surfaces puberulent to somewhat strigulose, mostly on the margin and veins beneath, hairs sparse to more numerous above; cystoliths numerous and conspicuous in dry state. Inflorescence either simply spiciform or more commonly branched, sometimes widely so and up to $25 \times 17 \mathrm{~cm}$, flowers laxly arranged along axes, solitary and sessile at each axil, opposite or more commonly monochasial, branching also sometimes monochasial, axes pale pubescent and with increasing density of puberulous hairs distally; bracts linear, $1.5-$ $3.5 \mathrm{~mm}$ long or those subtending inflorescence branches more foliaceous and up to $18 \times 10 \mathrm{~mm}$ long; bracteoles like linear bracts but somewhat shorter. Calyx divided almost to base into 5 linear lobes 2.8 $4.5 \mathrm{~mm}$ long, pubescent and puberulous, the latter hairs glandular but not capitate. Corolla $18-28 \mathrm{~mm}$ long, white with a pale greenish tube, lower lip with purple to blackish nectar guides, with mixed longer eglandular and shorter glandular hairs externally and lips with few to numerous short glandular hairs internally; tube \pm straight, narrowly cylindrical, 13.5 $20 \mathrm{~mm}$ long; upper lip lanceolate, $4-7 \times 1.5-3 \mathrm{~mm}$; lower lip 5-9 mm long, lobes $2-4 \times 2-3 \mathrm{~mm}$. Stamens inserted just below corolla mouth; filaments 2.8 - $3.5 \mathrm{~mm}$ long; anthers with thecae almost superposed and somewhat oblique, upper theca 0.5 $0.7 \mathrm{~mm}$ long, lower theca $0.8-1.1 \mathrm{~mm}$ long, the latter acute at base. Ovary $2-3 \mathrm{~mm}$ long, pubescent towards apex; style 14 - 22 mm long, pubescent. Capsule 13 $17.5 \mathrm{~mm}$ long, including sterile stipe $6-10 \mathrm{~mm}$ long, external surface covered in spreading hairs, with or without few glandular hairs; seeds $2.5-3 \mathrm{~mm}$ long, light brown to very dark brown, verruculose. Figs 1A C \& $2 \mathrm{~J}-\mathrm{K}$.

DISTRIBUTION. Rhinacanthus kaokoensis is largely restricted to the Kaokoveld centre of endemism, in Kunene region of northwest Namibia and Namibe and Cunene Provinces of southwest Angola. To date, it is known from ten collections (Map 1, red squares).

SPECIMENS EXAMINED. ANGOLA. Mossamedes [Namibe Prov.], Tampa, fl., 1 June 1937, Exell Eं Mendonça 2389 (BM); Huila [now Cunene Prov.], Vila Pereira d'Eça [Ondjiva], fl. \& fr., 11 June 1937, Exell Eं Mendonça 2933 (BM). NAMIBIA. 20 miles S of Ruacana, fl. \& fr., 14 June 1963, Giess E Leippert 7587 (WIND); am Kunene (Ruacana) bei Baken 1, fl. \& fr., 13 April 1966, Giess 9289 (WIND holotype; K, PRE isotypes); Opuwo Distr., track from Ruacana to Etoto village fl. \& fr., 7 March 2003, Klaassen EK 967 (WIND); Opuwo Distr., $18 \mathrm{~km} \mathrm{~W}$ of Okanguati on the road to Etengua, fl. \& fr., 2 Feb. 2006, Kolberg E Tholkes HK 1974 (WIND); idem, fl. \& fr., 15 April 2015, Nanyeni et al. LN 1044 (K, WIND); Opuwo Distr., on the bank of Oiva R., W of Ruacana, closer to Kunene Island Campsite, fl., 16 April 2015, Nanyeni et al. LN 1047 (WIND); Opuwo Distr., 10 miles away from Kunene R., at Ruacana Falls at the border, fl., 17 April 2015, Nanyeni et al. LN 1048 (WIND); Opuwo Distr., downstream from Ruacana falls at Namibia and Angolan border, fl. \& fr., 17 April 2015, Nyatoro et al. TN 0033 (K, WIND).

HABITAT \& ECOLOGY. This species occurs in dry bushland and woodland, typically in open Colophospermum mopane woodland, growing on gravel and granite hills or koppies. In some areas the plant grows in washes and on the banks of rivers especially in the Ruacana area. It occurs at $800-1250 \mathrm{~m}$ elevation.

CONSERVATION STATUS. This species is restricted to the Namibia-Angola border region, with an EOO of $36,073 \mathrm{~km}^{2}$ which is beyond the $20,000 \mathrm{~km}^{2}$ upper limit for the Vulnerable category under IUCN criterion B1. It is currently known from only five locations (considering the sites in the Ruacana area to be a single location). That said, in view of the distance between the two known Angolan locations, it is likely to be found in a number of additional sites there following more thorough investigation. In Namibia, the paucity of collections indicates that this species is scarce, although the steep, rocky terrain over large areas of northwest Namibia does mean that it is underbotanised away from the rather few roads. It was not found to be common either at Ruacana or near Okanguati during surveys in 2015 (I. Darbyshire \& L. Nanyeni, pers. obs.) and was not found in apparently suitable habitat elsewhere. At Ruacana, there has been some disturbance of suitable habitat associated with the hydro-electric dam and related infrastructure, together with expansion of the population around Ruacana town. One of the two known Angolan sites, Ondjiva, may also have been impacted by urbanisation. This town is the capital of Cunene Province, is situated c. $40 \mathrm{~km}$ from one of the main Namibian border crossings and has experienced significant expansion post civil-war. Further, the whole AngolanNamibian border region has experienced strong population growth over several decades (Pröpper 2009) and increased land use change is also expected to occur in the Cunene River Basin with rehabilitation and expansion of large irrigated schemes, targeting small, medium and large commercial farmers (see http://www.riverawarenesskit.com/). However, there is still extensive intact habitat across most of its range. In view of its scarcity and the threats to some of its known locations, it is provisionally assessed as Near Threatened (NT) under criterion B but this may be downgraded to Least Concern if it is found to be more common in southern Angola.

NOTES. Rhinacanthus kaokoensis has previously been reported from Angola (Darbyshire \& Harris 2006: 417) 

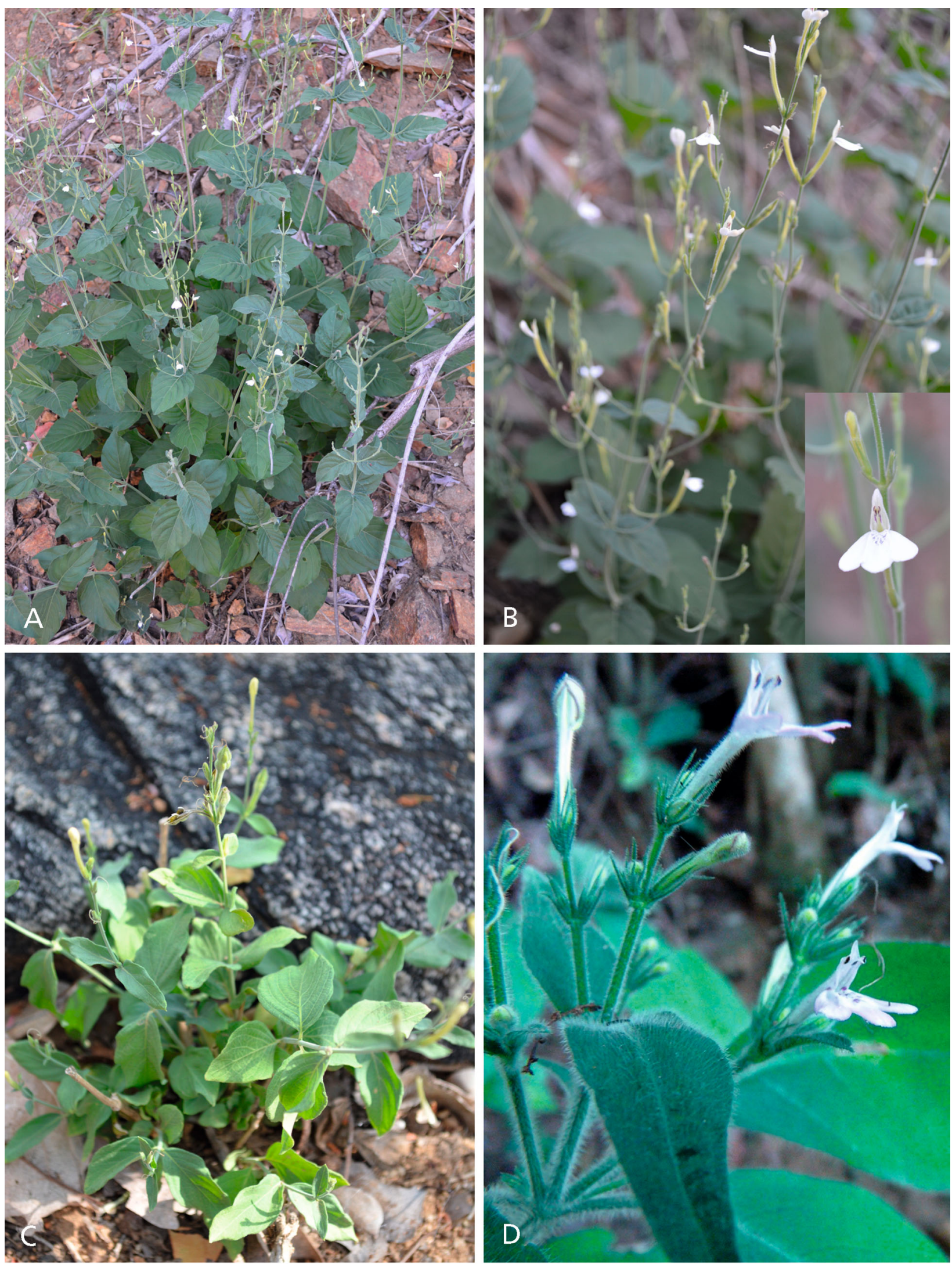

Fig. 1. Photographs of Rhinacanthus in the field. A - C R. kaokoensis, A and B in flower, Ruacana Falls, Namibia (collected as Nanyeni et al. LN 1048), C in fruit, W of Okanguati, Namibia (collected as Nanyeni et al. LN 1044). D R. virens, from Guinea (collected as P. K. Haba 490). PHOTOS: A - CI. DARBYSHIRE; D X. VAN DER BURGT. 


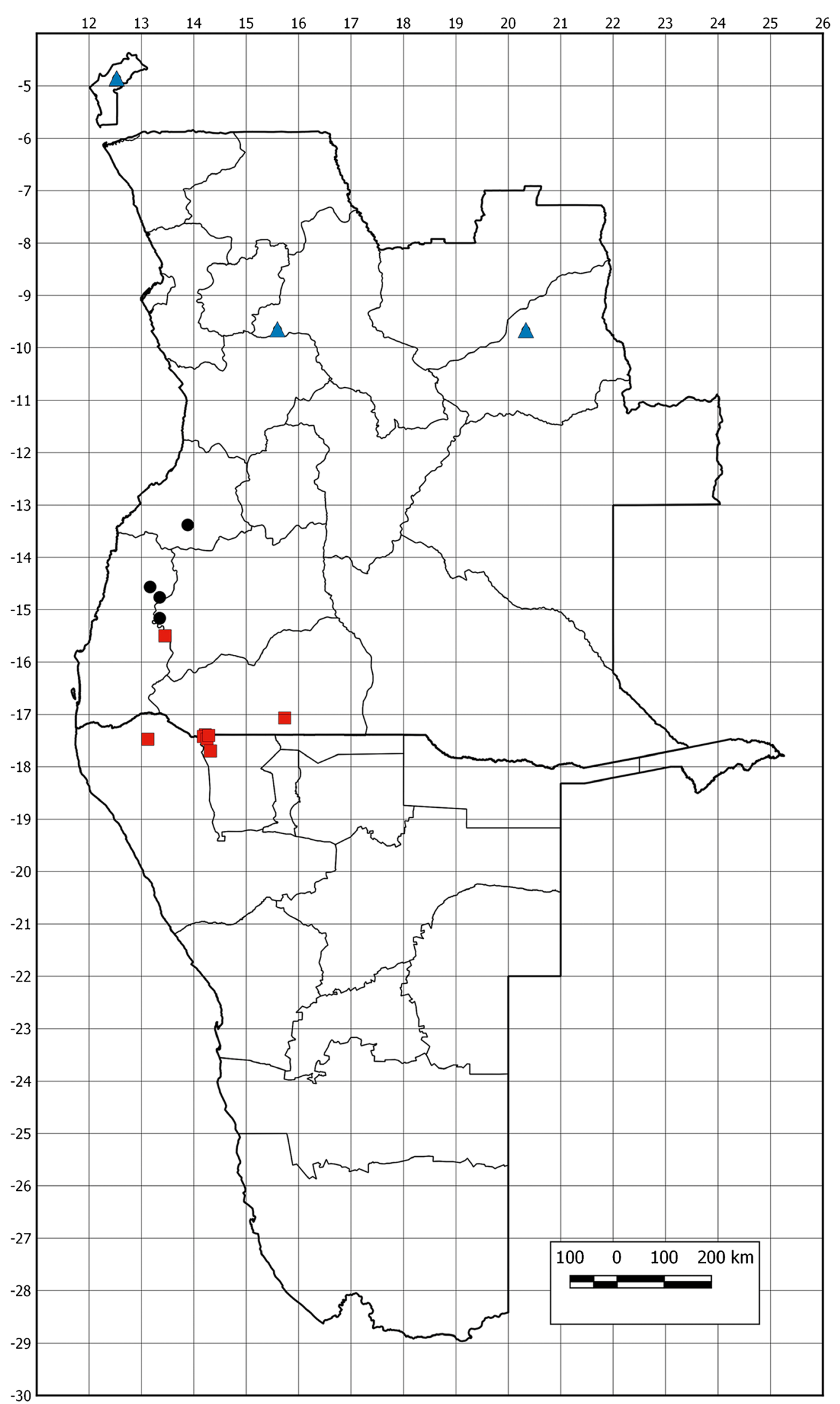

Map 1. Distribution of Rhinacanthus species in Angola and Namibia. $R$ kaokoensis (red squares), $R$. angolensis (black circles) and R. virens (blue triangles). 
but without specimen citations, and it was not listed in the Plants of Angola checklist (Makholela 2008). The two Angolan specimens cited here have a more widely branched inflorescence than in the Namibian material but are otherwise a close match. In view of the fact that these specimens and a number of new collections from Namibia have come to light since the protologue showing a wider range of morphological variation, a full description is provided.

This species is easily separated from its allies within the Rhinacanthus nasutus (L.) Kurz complex by lacking broad capitate ("mushroom-shaped") glandular hairs on the inflorescence. It is otherwise similar to $R$. xerophilus A. Meeuse from southeast Botswana, southern Zimbabwe, southern Mozambique and northeast South Africa (Balkwill 1995; Darbyshire et al. 2015). It shares with that species broadly ovate leaves and rather small corollas with a straight tube, but, it additionally differs in the foliage being less densely hairy when young and in the inflorescences being predominantly monochasial rather than having mostly opposite flowers along the axes, at least on the lateral inflorescence branches.

2. Rhinancanthus angolensis $I$. Darbysh. sp. nov. Type: Angola, Moçamedes [Namibe], Vila Arriaga [Bibala], fl. \& fr., 22 June 1959, Teixeira $\mathcal{E} \sigma$ Santos 41 (holotype LUBA [LUBA000576-0]).

http:/ /www.ipni.org/urn:lsid:ipni.org:names:77176548-1

Rhinacanthus communis sensu auctt. pro parte quoad Welwitsch 5010, non Nees: Clarke (1900: 224); Hiern (1900: 823).

Rhinacanthus nasutus sensu Makholela (2008: 24), pro parte, non (L.) Kurz.

Perennial herb, possibly sometimes short-lived, 15 $90 \mathrm{~cm}$ high, proximal portion of stems can be prostrate, distal portion ascending; stems somewhat angular, pubescent with mixed pale antrorse and retrorse hairs throughout, hairs becoming more sparse on mature stems, basal-most stems somewhat woody but rootstock small (Pritchard 356). Leaves can be largely absent at flowering; petiole up to $23 \mathrm{~mm}$ long; lower cauline leaves with blade ovate to elliptic, up to $11-12.7 \times 5.5-6.8 \mathrm{~cm}$, base cuneate, attenuate, margin entire, apex acute or subattenuate; uppermost cauline leaves sessile or shortly petiolate, $2.7-4.7 \times 1-2.5 \mathrm{~cm}$, base can be rounded; surfaces pubescent, hairs most numerous on veins beneath, sparse above particularly at maturity; lateral veins $4-7$ pairs, pale beneath. Inflorescence a lax panicle up to $20-60 \times 7-20 \mathrm{~cm}$ when mature but can be smaller, lateral branching often partially or wholly monochasial, sometimes with more than one branch developing at an inflorescence node, branches divergent giving the inflorescence an angular appearance; flowers held in fascicles of $2-5$ at apices of ultimate branches, fascicle peduncles typically $10-23 \mathrm{~mm}$ long, or fascicles rarely subsessile; proximal portion of main inflorescence axis with indumentum as that of stems, distal portion and main lateral branches mixed patent eglandular- and glandular-puberulous, the glandular hairs with a broad capitate gland-tip, and with \pm numerous longer patent eglandular-pilose hairs to $1 \mathrm{~mm}$ long; fascicle peduncles usually with these longer hairs few or lacking; bracts along main inflorescence axis foliaceous, can be caducous, gradually reducing in size upwards, those in midportion of inflorescence typically elliptic to lanceolate, $18-45 \times 7-19 \mathrm{~mm}$; fascicle bracts and bracteoles minute, linear-lanceolate, 1 - $2 \mathrm{~mm}$ long. Calyx divided almost to base into 5 linear lobes 2.3 $3.7 \mathrm{~mm}$ long in flower, marginally longer in fruit, puberulous with mixed eglandular and capitateglandular hairs externally. Corolla 25 - 32 mm long, white or pink, with purple (?) markings on palate of lower lip, pubescent externally with mixed eglandular and glandular hairs, lips with few short glandular hairs internally; tube at first straight but becoming \pm curved upwards at anthesis, narrowly cylindrical, 18.5 - $23 \mathrm{~mm}$ long; upper lip lanceolate, 5 $7 \times 2.5-2.7 \mathrm{~mm}$; lower lip $7-10 \mathrm{~mm}$ long, lobes $3-$ $5 \mathrm{~mm}$ long. Stamens inserted just below corolla mouth; filaments $2.8-3.5 \mathrm{~mm}$ long; anthers with thecae almost superposed and somewhat oblique, upper theca 0.75 $0.9 \mathrm{~mm}$ long, lower theca $1-1.25 \mathrm{~mm}$ long, the latter acute at base. Ovary $\pm 2 \mathrm{~mm}$ long, sparsely pubescent towards apex; style $18-22 \mathrm{~mm}$ long, sparsely pubescent mainly in proximal half. Capsule 13.5 - $14.5 \mathrm{~mm}$ long, including sterile stipe $6.5-7.5 \mathrm{~mm}$ long, external surface eglandular- and glandular-puberulous; seeds black, lenticular, $\pm 2.5 \mathrm{~mm}$ in diameter, minutely verruculose. Fig. $2 \mathrm{~A}-\mathrm{H}$.

RECOGNITION. Rhinacanthus angolensis differs from all the other known African species of the $R$. nasutus complex (sensu Darbyshire \& Harris 2006) in having long patent eglandular hairs on the inflorescence axes in addition to being glandular- and eglandularpuberulous (but see Notes section below). It otherwise most closely resembles $R$. latilabiatus (K. Balkwill) I. Darbysh. from South Africa, sharing a similar inflorescence form in which the flowers are held in fascicles terminating the inflorescence branches. The new species differs in (1) the stems being only subangular with inconspicuous ridges and evenly distributed hairs, vs hairs concentrated on the prominent pale ridges in R. latilabiatus; (2) the corolla tube being curved upwards at maturity, vs straight; and (3) the leaves being broader, with a length : width ratio $1.7-2.1: 1$, 


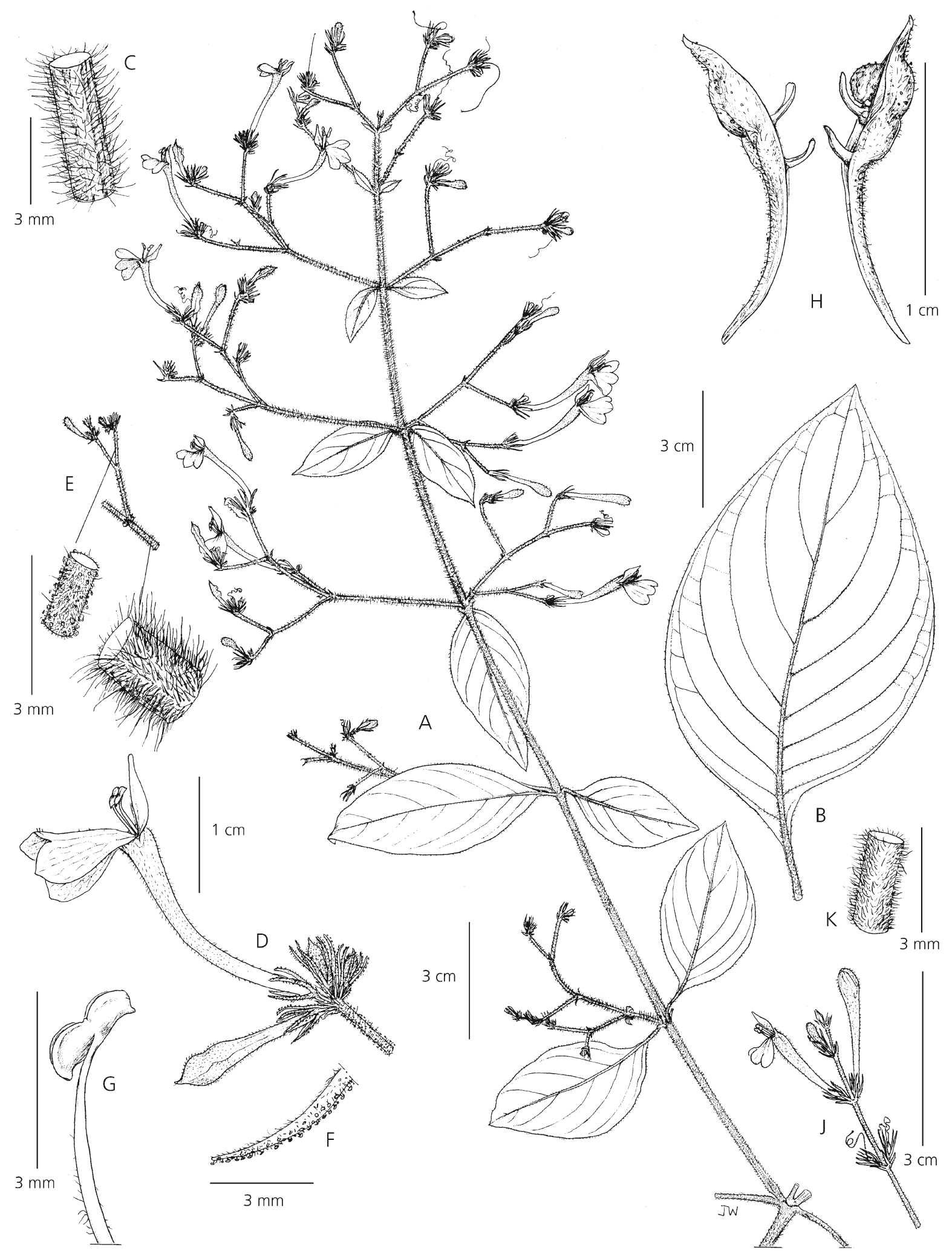

Fig. 2. A - H Rhinacanthus angolensis. A habit, flowering stem; B mature leaf, abaxial surface; C detail of stem indumentum; D partial inflorescence with mature corolla; $\mathrm{E}$ details of inflorescence indumentum including long spreading eglandular hairs and short glandular hairs; F detail of calyx lobe; G stamen; $\mathrm{H}$ capsule, opened, one valve with seed. J, K Rhinacanthus kaokoensis. J partial inflorescence with corolla; $\mathrm{K}$ detail of inflorescence indumentum. A, C, D, F \& G from Teixeira \& Santos 41, B \& H from Correia 761, E from Pritchard 356, J \& K from Nyatoro et al. TN 0033. DRAWN BY JULIET WILLIAMSON. 
vs typically $2.3-4.4: 1$ in $R$. latilabiatus. The new species is also similar to $R$. zambesiacus I. Darbysh. from southern tropical Africa but is easily separated by the differing inflorescence form, $R$. zambesiacus having flowers laxly arranged in pairs or singly along the spiciform inflorescence axis and (if present) branches rather than in terminal fascicles. Rhinacanthus zambesiacus also has a straight or at most very shallowly curved corolla tube. Rhinacanthus dichotomus (Lindau) I. Darbysh. from East Africa often has an intermediate inflorescence form in which some flowers are clustered at the ends of the branches with others arranged in pairs or singly along the axes. It could, therefore, be confused with $R$. angolensis but clearly differs by its leaves being glabrous adaxially, the blade of the lower cauline leaves more elliptic or obovate, the corolla tube being more markedly sigmoid-curved and in the lower lip of the corolla either being speckled throughout (var. dichotomus) or completely lacking markings (var. emaculatus) rather than in having markings in the throat and central palate only. See Table 1.

DISTRIBUTION. Rhinacanthus angolensis is restricted to southwest Angola, where it is recorded from Benguela, Huíla and Namibe provinces (Map 1, black circles).

SPECIMENS EXAMINED. ANGOLA. Distr. Bumbo, Serra de Chela, fl., Oct. 1859, Welwitsch 5010 (BM, LISU); Tchivinguiro, fl. \& fr., 3 Aug. 1954, Pritchard 356 (BM 2 sheets); Moçamedes [Namibe], Vila Arriaga [Bibala], fl. \& fr., 22 June 1959, Teixeira E Santos 41 (holotype LUBA); Moçamedes [Namibe], entre Montipa e Perangombe, fl., 22 June 1959, Teixeira $\mathcal{E}^{\circ}$ Santos 3867 (LUBA); Benguela, próxim. Caporolo (R. Caporolo), fl., 24 June 1959, Correia 761 (LUBA).

HABITAT \& ECOLOGY. Habitat information for this species is limited; Pritchard recorded it from amongst calcareous rocks by the roadside, whilst Teixeira $\mathcal{E}^{\circ}$ Santos (3867) recorded it from shaded places in areas of low moisture. From its known range, it is likely to be found in dry woodland and bushland, occurring at $\mathrm{c}$. 600 - 1700 m elevation.

CONSERVATION STATUS. This species is currently known from five collections of which the Welwitsch specimen has not been precisely located. Based on the remaining four collections, the EOO is $3890 \mathrm{~km}^{2}$ which would potentially fall within the Endangered category under IUCN (2012) criterion B1. Pritchard recorded it as common at Tchivinguiro in 1954, but analysis of Google Earth imagery and personal observations (F. M. P. Gonçalves) shows that this area of the Lubango escarpment is now extensively settled with considerable loss of natural habitat due primarily to increasing demand for charcoal production. The same is true of the Bibala area, where clearance of large dry forest patches for charcoal can be seen along the escarpment. However, as with most of Angola, this species' range remains under-botanised and it is quite possible that Rhinacanthus angolensis is more common or widespread than it currently appears. Without recent information on the status and threats to its populations, and with very little habitat information available, $R$. angolensis must currently be considered Data Deficient (DD).

NOTES. Rhinacanthus angolensis is compared to three fully documented species of the $R$. nasutus complex in the Recognition section above and a summary of the diagnostic characters is provided in Table 1; $R$. kaokoensis is also included in that table for completeness as it is geographically closest to $R$. angolensis. One further, incompletely known species from southern Tanzania is also worthy of note here: R. sp. A (= Ward U70) of Flora of Tropical East Africa (Darbyshire et al. 2010). The single collection known of that taxon lacks leaves, but it shares with $R$. angolensis the long patent hairs in addition to the shorter glandular and eglandular indumentum on the inflorescence, albeit more sparsely so and largely confined to the main inflorescence axis. It also has similarly fascicled flowers. It differs primarily in having larger capsules 17 - $21 \mathrm{~mm}$ long and seeds $3.2-$ $3.8 \mathrm{~mm}$ in diameter, and in having a shallowly sigmoid-curved corolla tube similar to $R$. dichotomus. A close relationship between these two taxa seems improbable in view of the wide geographic separation. That said, several cases of disjunctions in African Acanthaceae are not wildly dissimilar. In Barleria, B. pseudosomalia I. Darbysh. is known from a small area of central Tanzania and a single collection from NE Namibia (Darbyshire et al. 2012); and a close similarity has been noted between the variant of Barleria taitensis S. Moore found in central Tanzania and B. taitensis var. occidentalis S. Moore from NW Namibia and SW Angola (Darbyshire et al. 2010 \& in prep.). In Ruellia, R. bignoniifolia S. Moore also has a marked east-west disjunction; it occurs from Ethiopia and South Sudan south to Zimbabwe and Mozambique, but is also recorded from Angola (including the type locality) and Namibia (Tripp \& Dexter 2012; Vollesen 2013).

3. Rhinancanthus virens (Nees) Milne-Redh. (in Exell 1956: 37); Heine (1963: 425 excl. var. obtusifolius; 1966 : 201, pl. 42); Darbyshire \& Harris (2006: 414); Daniel \& Figueiredo (2009: 666); Darbyshire et al. (2010: 603; 2015: 229). Type: Gabon, "Gaboon coast", fr., 1787, Middleton s.n. (holotype K [K000378880]). Fig. 1D.

Leptostachya virens Nees (1847: 378).

Rhinacanthus dewerrei De Wild. \& T. Durand (in Durand \& De Wildeman 1899: 105); Exell (1944: 263). Type: D. R. Congo, Bokakata, fl., 6 Feb.1896 [recorded as 10 March 1896 in protologue], Dewè̀re 804 [no. not listed in protologue] (holotype BR [BR000000629409, BR000000851635]; isotype K [K000378881]), see note. 


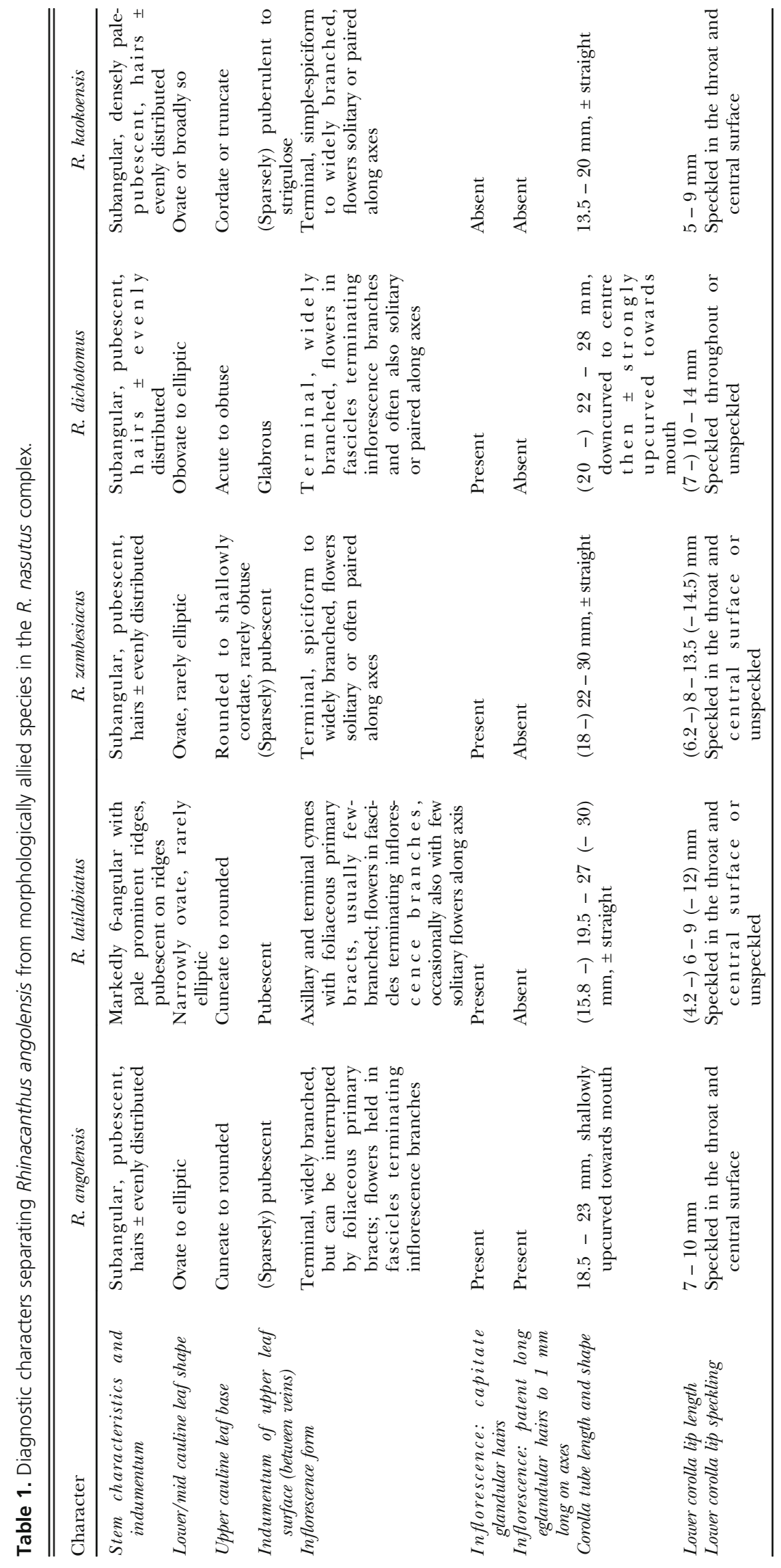


Rhinacanthus parviflorus T. Anderson, nom. nud.; Durand \& De Wildeman (1899: 106, in obs.).

Rhinacanthus communis sensu auctt., non Nees: Clarke (1900: 224, 514), pro parte; Hutchinson \& Dalziel (1931: 266).

Rhinacanthus subcaudatus C. B. Clarke (1900: 225). Types: Guinea [see note], near the Scarcies R., Wallia, Scott-Elliot 4276 (syntype K [K000378884]) \& near Sasseni, Scarcies, fl. \& fr., 13 Jan., Scott-Elliot 4428 (syntype K [K000378885]); without location [presumed to be from Sierra Leone], Afzelius 2 [no. not recorded in protologue] (syntype BM [BM001209603])

Siphonoglossa rubra S. Moore (1906: 88). Type: Uganda, Entebbe, fl. 15 Nov. 1905, Bagshawe 750 (holotype BM [BM000931254]).

Rhinacanthus minimus S. Moore (1920: 47); Darbyshire \& Harris (2006: 416). Type: D. R. Congo, Bukala, fl. \& fr., 1914, Vanderyst 4972 (holotype BM [BM000931255]; isotype BR [BR0000008516183]).

DISTRIBUTION. Rhinacanthus virens is widespread in the Guineo-Congolian phytogeographical region, extending from Sierra Leone to Uganda, NW Tanzania, D. R. Congo, NW Zambia and N Angola. In Angola it is recorded in Cabinda, Cuanza Norte and Lunda Sul Provs., but is also likely to occur in Lunda Norte Prov. (Map 1, blue triangles). SPECIMENS EXAMINED. ANGolA. Pungo Andongo, Mata de Pungo, fl., May 1857, Welwitsch 5191 (BM); at the Furnas [?] Antonio Victorino, R. Lococuto, Buco Zau, fl., 9 Aug. 1916, Gossweiler 6576 (BM); Maiombe, BucoZau, near official residence at Belize, fl. \& fr., 16 Nov. 1918, Gossweiler 7564 (BM, LISC 2 sheets). Lunda Sul Prov.: tributary of R. Chikapa [Chicapa], Saurimo, fl. \& fr., 5 Aug. 1932, Young 393 (BM, LISC).

HABITAT \& ECOLOGY. This species is recorded from wet forest including riverine fringing forest. In Angola it is recorded at c. 50 - $1000 \mathrm{~m}$ elevation.

CONSERVATION STATUS. Rhinacanthus virens is widespread and common in the Guineo-Congolian forest region and is assessed as of Least Concern (LC) (Ghogue 2010). The EOO is over $5,000,000 \mathrm{~km}^{2}$. It is localised in Angola, but Gossweiler noted it as "common skirting the forests" in the Maiombe region. NOTES. Detailed descriptions of this species are available in Heine (1966), Daniel \& Figueiredo (2009) and Darbyshire et al. $(2010,2015)$ and are not repeated here. The material seen from Angola is very variable, reflecting the considerable variation within this species as a whole. The collection from Lunda Sul is of a slender, small-flowered form with corollas up to $15 \mathrm{~mm}$ long and calyx lobes c. $3 \mathrm{~mm}$ long, resembling plants from west Zambia described in Darbyshire et al. (2015). Very similar plants are found elsewhere in the range of $R$. virens, for example in Sierra Leone and Guinea. Gossweiler 7564 from Cabinda has markedly larger flowers up to $24 \mathrm{~mm}$ long with calyx lobes c. $4.5 \mathrm{~mm}$ long, typical of the widespread Congolian form of this species. However, that specimen also differs markedly from the second collection from Cabinda (Gossweiler 6576) in having much narrower leaves and partial inflorescences with more flowers.

The two Scott-Elliot syntypes of Rhinacanthus subcaudatus were made under the Sierre Leone Boundary Commission and the collecting localities have previously been listed as being in Sierra Leone (Darbyshire et al. 2010). However, Gledhill (1969) notes that Wallia and Sasseni are both in modern-day Guinea and that the collecting locality on the Scarcies River near Sasseni is also likely to have been on the Guinea side of the border. The type of $R$. dewevrei was listed in the protologue as having been collected on 10 March 1896 and no collecting number was cited. The labels on one of the BR sheets (BR000000851635) and on the Kew isotype have been added later and give the date of collection as 6 February 1896 and the collecting number as Dewère 802. It is not clear which date is correct for this collection.

As noted in the Introduction, recent molecular evidence (Kiel et al. 2017) places Rhinacanthus virens outside of the core Rhinacanthus clade. Instead, it forms one of two basal lineages in the Diclipterinae clade and is sister to the rest of Diclipterinae including core Rhinacanthus. Kiel et al. (2017) note the differing ecology (wet forest vs more arid habitats) together with the broader, triangular ovate upper lip (see Fig. 1D), shortly appendaged lower anther theca and pollen with insulae (vs bands in core Rhinacanthus) as evidence to support its separation. That said, $R$. virens is still morphologically similar to the $R$. nasutus complex and, indeed, was included within a broadly circumscribed $R$. communis (=R. nasutus) by Clarke (1900). For a more complete understanding of the relationship between $R$. virens and core Rhinacanthus, the other forest species of Rhinacanthus - R. obtusifolius (Heine) I. Darbysh., R. submontanus T. Harris \& I. Darbysh. and R. selousensis I. Darbysh. (see Darbyshire \& Harris 2006) — should be prioritised for sequencing in future molecular studies. For the present time, $R$. virens is maintained in Rhinacanthus sensu lato.

\section{Acknowledgements}

The Namibian component of this research, including fieldwork and research visits to WIND herbarium, was supported by the Southern African Science Service Centre for Climate Change and Adaptive Land Management (SASSCAL) programme, Task 060 - "Establish and Improve baseline inventories for spatial data and biodiversity - Flora of Namibia Project". We particularly thank Mrs Esmerialda Strauss, Head of the National Botanical Research Institute (NBRI) of Namibia for overseeing this programme task and for kindly facilitating the research visits of I. Darbyshire to Namibia in 2014 and 2015. We also thank Prof. Fernanda Lages, Head of the Collections at the Instituto Superior de Ciências de Educação, Huíla for her kind assistance in providing access to collections from the 
LUBA herbarium, and Jacek Wajer and Ranee Prakash of the Natural History Museum, London (BM herbarium) for providing access to their holdings of Rhinacanthus. David Aiyambo and Tanaka Nyatoro of NBRI are thanked for their contributions to fieldwork in 2015. Kind thanks also go to Juliet Beentje for producing the excellent illustration of $R$. angolensis and Xander van der Burgt for providing access to his photograph of $R$. virens.

Open Access This article is distributed under the terms of the Creative Commons Attribution 4.0 International License (http://creativecommons.org/ licenses/by/4.0/), which permits unrestricted use, distribution, and reproduction in any medium, provided you give appropriate credit to the original author(s) and the source, provide a link to the Creative Commons license, and indicate if changes were made.

\section{References}

Amarasinghe, A. P. P. R. \& Wijesundara, D. S. A. (2011). A new species of Rhinacanthus (Acanthaceae) from Sri Lanka. Edinburgh J. Bot. 68: 333 - 337.

Bachman, S., Moat, J., Hill, A. W., de la Torre, J. \& Scott, B. (2011). Supporting red list threat assessments with GeoCAT: Geospatial conservation assessment tool. ZooKeys 150: 117 - 126.

Balkwill, K. (1995). Rhinacanthus, pp. 11 - 14. In: O. A. Leistner (ed.), Flora of Southern Africa Vol. 30, Pt. 3: Acanthaceae, Fascicle 1: Justiciinae. National Botanical Institute, Pretoria, South Africa.

Benoist, R. (1950). Quelques Acanthacées des colonies Portugaises Africanes. Bol. Soc. Brot. Sér. 2(24): 5 - 39.

Chase, F. (2017). The Flora of Namibia. National Botanical Research Institute. Available at: http:// www.nbri.org.na/projects/the-flora-of-namibia. Accessed 28 Sept. 2017.

Clarke, C. B. (1900). Rhinacanthus, pp. 224 - 226 \& 514. In: W. T. Thiselton-Dyer (ed.), Flora of Tropical Africa 5. L. Reeve \& Co., London.

Craven, P. (ed.) (1999). A checklist of Namibian plant species. Southern African Botanical Diversity Network Report No. 7, SABONET, Windhoek.

Daniel, T. F. \& Figueiredo, E. (2009). The California Academy of Sciences Gulf of Guinea Expeditions (2001, 2006, 2008). VII. Acanthaceae of São Tomé and Príncipe. Proc. Calif. Acad. Sci. Ser. 4, 60:623-674.

Darbyshire, I. (2012). A new name for the Zambesian Rhinacanthus (Acanthaceae). Kew Bull. 67: 767 - 769.

(2015). The genus Hypoestes (Acanthaceae) in Angola. Kew Bull. 70: 44 (10 pages).

\& Harris, T. (2006). Notes on the genus Rhinacanthus (Acanthaceae) in Africa with a synopsis of the $R$. nasutus-R. gracilis complex and a key to the African members of the genus. Kew Bull. 61: $401-418$.
Tripp, E. A. \& Dexter, K. G. (2012). A new species and a revised record in Namibian Barleria (Acanthaceae). Kew Bull. 67: 759 - 766.

, Vollesen, K. \& Ensermu Kelbessa (2010). Acanthaceae (Part 2). In: H. J. Beentje (ed.), Flora of Tropical East Africa. Royal Botanic Gardens, Kew.

Vollesen, K. \& Ensermu Kelbessa (2015). Acanthaceae (Part 2). In: J. R. Timberlake \& E. S. Martins (eds), Flora Zambesiaca Vol. 8, Pt. 6. Royal Botanic Gardens, Kew.

Durand, T. \& De Wildeman, E. (1899). Matériaux pour la Flore du Congo. Quatrième fascicule. Compt. Rend. Soc. Bot. Belg. 38: 78 - 116.

Ensermu Kelbessa (2006). Acanthaceae, pp. 345 - 495. In: I. Hedberg, Ensermu Kelbessa, S. Edwards, Sebsebe Demissew \& E. Persson (eds), Flora of Ethiopia $\mathcal{E}$ Eritrea Vol. 5. The National Herbarium, Addis Ababa University, Ethiopia \& The Department of Systematic Botany, Uppsala University, Sweden.

(2009). Three new species of Acanthaceae from Ethiopia. Kew Bull. 64: 57 - 65.

Exell, A. W. (1944). Catalogue of the Vascular Plants of S. Tomé (with Principe and Annobon). British Museum, London.

(1956). Supplement to the Catalogue of the Vascular Plants of S. Tomé (with Principe and Annobon). British Museum, London.

Ghogue, J.-P. (2010). Rhinacanthus virens. The IUCN Red List of Threatened Species 2010: e.T185209A8367146. Available at: https:/ / doi.org/10.2305/IUCN.UK.20103.RLTS.T185209A8367146.en. Accessed 15 Dec. 2016.

Gledhill, D. (1969). G. F. Scott-Elliot and his plant localities. Taxon 18: 425 - 428.

Heine, H. (1963). Acanthaceae, pp. 391 - 432. In: F. N. Hepper (ed.), Flora of West Tropical Africa. Vol. 2. Second edition. Royal Botanic Gardens, Kew.

(1966). Flore du Gabon 13. Acanthacées. Muséum National d'Histoire Naturelle, Paris, France.

Hiern, W. P. H. (1900). Catalogue of the African plants collected by Friedrich Welwitsch in 1853 - 1861. Dicotyledons, part IV Lentibulariaceae to Ceratophylleae. British Museum (Natural History), London.

Hutchinson, J. \& Dalziel, J. M. (1931). Flora of West Tropical Africa. Volume 2, Part 1. The Crown Agents for the Colonies, London.

IUCN (2012). IUCN Red List Categories and Criteria. Version 3.1. Second Edition. IUCN Species Survival Commission, Gland \& Cambridge.

Kiel, C. A., Daniel, T. F., Darbyshire, I. \& McDade, L. A. (2017). Unraveling relationships in the morphologically diverse and taxonomically complex 'justicioid' lineage (Acanthaceae). Taxon 66: 645 - 674.

Klaassen, E. \& Kwembeya, E. (eds) (2013). A checklist of Namibian indigenous and naturalised plants. Occasional Contributions No. 5, National Botanical Research Institute, Windhoek, Namibia. 
Madagascar Catalogue (2017). Catalogue of the Vascular Plants of Madagascar. Missouri Botanical Garden, St. Louis \& Antananarivo, Madagascar. http:// www.efloras.org/madagascar. Accessed January 2017.

Makholela, T. (2008). Acanthaceae, pp. 21 - 25. In: E. Figueiredo \& G. F. Smith (eds), Plants of Angola / Plantas de Angola. Strelitzia 22. South African National Biodiversity Institute, Pretoria.

McDade, L. A., Daniel, T. F., Masta, S. E. \& Riley, K. M. (2000). Phylogenetic relationships within the tribe Justicieae (Acanthaceae): evidence from molecular sequences, morphology, and cytology. Ann. Missouri Bot. Gard. 87: 435 - 458.

Meyer, P. G. (1968). 130. Acanthaceae. In: H. Merxmüller (ed.), Prodromus einer Flora von Südwestafrika. J. Cramer, Lehre.

Moore, S. (1906). Uganda gamopetalae from Dr. Bagshawe. J. Bot. 44: 83 - 90.

(1920). Alabastra diversa - Part XXXII. 1. Plantae Congoenses novae vel rariores. J. Bot. 58: $44-48$.

Nees von Esenbeck, C. G. D. (1847). Acanthaceae, pp. 46 - 519. In: A. de Candolle (ed.), Prodromus Systematis Naturalis Regni Vegetabilis 11. Masson, Paris.

Nyirenda, F. C. (2012). Morphological variation in five related species of Barleria (Acanthaceae). Unpubl. M.Sc. thesis, University of Witwatersrand, Johannesburg.

Pröpper, M. (2009). Culture and Biodiversity in Central Kavango, Namibia. Reimer, Berlin.

Steyn, H. \& van Wyk, A. E. (2015). Taxonomic notes on the Acanthopsis disperma-hoffmannseggiana complex (Acanthaceae, tribe Acantheae), with an interim key to members of the genus. Phytotaxa 219: $1-26$.
$\&$ (2016). Taxonomic notes on the shrublet species of Acanthopsis (Acanthaceae, tribe Acantheae), with two new species from South Africa. Phytotaxa 244: 145 - 160.

\& (2017). Taxonomic notes on Acanthopsis Harv. (Acanthaceae, tribe Acantheae): the group with trifid bracts. Phytotaxa 295: $201-217$.

Thulin, M. (2006). Rhinacanthus, pp. 400 - 401. In: M. Thulin (ed.), Flora of Somalia. Vol. 3. Royal Botanic Gardens, Kew.

Tripp, E. A. \& Darbyshire, I. (2017). Phylogenetic relationships among Old World Ruellia L.: a new classification and reinstatement of the genus Dinteracanthus Schinz. Syst. Bot. 42: 470 - 483.

\& Dexter, K. G. (2012). Taxonomic novelties in Namibian Ruellia (Acanthaceae). Syst. Bot. 37: 1023 - 1030 .

, Tsai, Y.-H. E., Zhuang, Y. \& Dexter, K. (2017). RADseq dataset with $90 \%$ missing data fully resolves recent radiation of Petalidium (Acanthaceae) in the ultra-arid deserts of Namibia. Ecol. Evol. 7: 7920 - 7936. https://doi.org/10.1002/ece3.3274.

Vollesen, K. (2013). Acanthaceae (Part 1). In: J. R. Timberlake \& E. S. Martins (eds), Flora Zambesiaca Vol. 8, Pt. 5. Royal Botanic Gardens, Kew.

Wallich, N. (1832). Plantae Asiaticae Rariores; or, Descriptions and figures of a select number of unpublished East Indian plants. Vol. III. Treuttel \& Würtz, London, Paris, Strasbourg [Strasburgh].

Welman, W. G. (2003). Acanthaceae. In: G. Germishuizen \& N. L. Meyer (eds), Plants of southern Africa: an annotated checklist. Strelitzia 14: 92 - 106. National Botanical Institute, Pretoria. 